\title{
Ukrainos demokratijos vingiai arba dar kartą apie politinį šalies nestabilumą
}

\begin{abstract}
Mokslinëje literatūroje politiniam procesui Ukrainoje apibūdinti dažnai vartojamas politinio nestabilumo arba tiksliau politinio režimo nestabilumo konceptas. Mokslininku manymu, šalies politinị stabilumą/nestabilumą lemia du svarbiausi veiksniai: „politinio rungtyniavimo" tarp svarbiausių politiniu jègu ypatybès bei aukščiausios vykdomosios valdžios politinèje sistemoje funkcionavimo pobūdis. Šiame straipsnyje remiantis amerikiečių tyrinėtojų Jack Golsdtone ir Jay Ulfelder pasiūlytų kriteriju pagalba bus aptariama Ukrainos politinio režimo dinamika po Oranžinès revoliucijos. Esminė nuostata, kuria remiasi analizè - Ukrainos demokratiniam režimui dar pakankamai ilgą laiką bus būdingas politinis nestabilumas.
\end{abstract}

\section{İvadas. \\ Keli metodologinio pobūdžio pastebèjimai}

Demokratinio politinio režimo Ukrainoje įsitvirtinimo arba, kaip yra labiau priimta politikos moksluose teigti, jos konsolidacijos problemos dažnai ir plačiai aptarinëjama problema. Impulsą naujiems tyrinëjimams suteiké politiniai įvykiai $2004 \mathrm{~m}$. pabaigoje ir $2005 \mathrm{~m}$. pradžioje, kurie mokslinëje ir populiarioje literatūroje paprastai vadinti Oranžine revoliucija. Daugybei tyrinètoju ir politinių stebètojų daliai atrodè, jog revoliucija bus tas sukrètimas ir impulsas, kuris ne tik pasuks Ukrainos užsienio politiką labiau link vakarietiškos orientacijos, bet ir padès sukurti skaidresni, demokratiškesnį politinės sistemos modelį, labiau kaip „Vidurio Europos ${ }^{\text {"1 }}$. Šiame kontekste iš esmès teigiamai buvo vertinama ir vadinamoji konstitucinė reforma, kuri formaliai pradejo veikti nuo $2006 \mathrm{~m}$. pradžios, ir pagal kurią daugiau galiu igijo parlamentas (Aukščiausioji Rada.) Taip Ukraina iš prezidentinės turëjo virsti parlamentine - prezidentine respublika. Tiesa, būtina pažymėti, jog „,konstitucinè

\footnotetext{
${ }^{*}$ Dr. Vladas Sirutavičius - Vilniaus universiteto Tarptautiniu santykiu ir politikos mokslu instituto docentas. Adresas: Vokiečiu g. 10, 01130 Vilnius, tel. 8526268 43, el. paštas - vsir@takas.lt

${ }^{1}$ Moshes A., „Ukraine: Domestic Changes and Foreign Policy Reconfiguration“, Political Trends in the Eastern Europe: Ukraine and Belarus (ed. By V. Silitski and A. Moshes), 2007, p. 17, www. StrategicStudiesInstitute.army.mil.
} 
reforma" labiau priminè revoliucinių įvykių įkarštyje tarp dviejų kovojančių politinio elito grupių „oranžinių“, kurių priešakyje stovejjo V. Juščenka ir J. Timošenko, bei „mèlynai baltų“, kuriems vadovavo V. Janukovičius, pasiektą laikiną politinį kompromisą, nei aišku, gerai apgalvotą planą, kaip reformuoti šalies politinę sistemą.

Manytume, jog apskritai politinio proceso dinamikai Ukrainoje po Oranžinès revoliucijos apibūdinti geriausiai tiktu nestabilumo sąvoka. Politini nestabilumą šalyje liudijo keletas aplinkybių: pirma, Oranžinès revoliucijos laimètojams nepavyko užtvirtinti savo pergalès. $2005 \mathrm{~m}$. vid. prezidento Juščenkos ir vyriausybès vadovès Timošenko konfliktas baigėsi pastarosios atsistatydinimu; antra, kompromisai pasiekti tarp Juščenkos ir Janukovičiaus pasirodè esantis trumpalaikiai. Nors politinis susitarimas tarp dvieju lyderių ir jų vadovaujamu politinių jègu leido po didelių vargų suformuoti naują „oranžinių“ vyriausybę, vadovaujamą J. Jechanurovo, tačiau stabiliai dirbti ji negalèjo. Todèl 2006 m. kovo mẻn. organizuoti Rados rinkimai; trečia, nors formaliai rinkimus laimèjo „oranžinių" blokas, tačiau suformuoti stabilios daugumos ir susitarti dẻl svarbiausių politiniu postų pasidalijimo jo lyderiai nesugebejjo. V. Morozo socialistams prisijungus prie Janukovičiaus vadovaujamos „Regionu partijos“, pastarasis tapo vyriausybès vadovu; ketvirta, gilejant priešpriešai tarp Rados daugumos, vyriausybès iš vienos pusès ir prezidento iš kitos, Juščenka nutarè paleisti parlamentą ir paskelbti priešlaikinius rinkimus; penkta, priešlaikiniai rinkimai iš esmės politinių jẻgų santykio šalyje nepakeitė. Jie tik dar labiau paryškino tendenciją, jog Ukrainos politiniame žemėlapyje dominuoja dvi tarpusavyje konfrontuojančios politinès jègos: Janukovičiaus vadovaujama „Regionų partiją“, kurią labiausiai remia šalies pietinių ir rytiniu rajonu gyventojai, ir Timošenkos blokas, kurį palaikè šalies centriniai ir vakariniai rajonai. Tačiau nè viena iš tų politinių jẻgu pati viena daugumos Radoje neturi ir noredama suformuoti vyriausybę priversta ieškoti sajungininkų.

Politiniam Ukrainos procesui apibūdinti naudojome politinio nestabilumo arba tiksliau politinio režimo nestabilumo sąvoka. Derètų šiek tiek plačiau ją aptarti. Šiuolaikiniuose tyrinejjimuose, kuriuose pagrindinis analizès objektas yra struktūrinės politinès krizės ir valstybių žlugimas (ang. state failure), naudojamasi ir politinio nestabilumo konceptu². Mokslininkų manymu, šalies politinį stabilumą/nestabilumą lemia du svarbiausi veiksniai: „politinio rungtyniavimo" tarp svarbiausių politiniu jẻgų ypatybės bei aukščiausios vykdomosios valdžios politinejje sistemoje funkcionavimo pobūdis. Taigi stabiliu politiniu režimu galima laikyti „,uždaras autokratijas“, kuriose praktiškai visiškai eliminuota bet kokia politinio rungtyniavimo dèl valdžios galimybè, o

\footnotetext{
${ }^{2}$ Geru tokios analizès pavyzdžiu yra JAV mokslininkų grupès atliktas tyrimas, kuriame buvo aptariami valstybių žlugimo atvejai, priežastys ir pasekmès 1955-2006 metais. Žr. „Political Instability Task Force. Internal Wars and Failures of Governance“ (PITF). Tyrimas buvo pradėtas 1994 metais. Jis buvo atliekamas JAV vyriausybės užsakymu. Pagrindinis tyrimo tikslas: išsiaiškinti „valstybių pažeidžiamumo priežastis - nuo politinio nestabilumo iki valstybių žlugimo“. Su tyrimo medžiaga galima susipažinti interneto svetainejje, http://www.cidcm.umd.edu/projects/project. asp?id=19.
} 
aukščiausioji vykdomoji valdžia praktiškai neribojama jokiu kitu valstybiniu institutu. Stabilios yra ir liberalios demokratijos, tai tokie politiniai režimai, kuriose konkuruoja ,"atviros politinės partijos“, o galimybe kilti prievartai yra minimali. Taip pat svarbu, jog tokiame režime vykdomoji valdžia „stipriai apribota" nepriklausomų teismų bei įstatymų leidžiamosios valdžios ${ }^{3}$.

Jack Golsdtone ir Jay Ulfelder teigimu, labiausiai pažeidžiamas ir nestabilus yra toks režimas, kuris gali būti apibūdinamas kaip „nominalus“, formaliai demokratinis, tačiau kurio politiniam rungtyniavimui - konkurencijai tarp dominuojančiu politinių jègu - būdingas „ryškus susipriešinimas" (ang. factionalized political competition), ir kuriuose akivaizdžiai dominuoja vykdomoji valdžia. Susipriešinusiam politinès konkurencijos modeliui būdingi trys svarbiausiai bruožai: poliarizacija, „parapijiškumas“ (ang. parochialism) ir mobilizacija. „Parapijiškumas“ apibūdina toki politinės konkurencijos modeli, kuriame svarbiausios politinès partijos išreiškia siaurų socialinių ar ekonominių grupių interesus, jas vienokiu ar kitokiu būdu vertindamas kaip favoritus. Tokios politinės partijos neatlieka svarbiausios mediatoriaus, tarpininko, funkcijos tarp įvairių socialiniu grupių, bet tik dar labiau stengiasi pabrèžti tarp ju egzistuojančius skirtumus. Poliarizacija atsiranda tuomet, kai rungtyniavimas tarp pagrindinių politinių jẻgų dèl įtakos politiniam centrui virsta tarsi „nulinès sumos žaidimu“. Pralaimèjęs ne tik praranda turètą politinę poziciją, bet ir susiduria su ekonominiu spaudimu bei politiniu persekiojimu. Galiausiai konkuruojančios politinès jëgos, siekdamos igyvendinti savo „parapijinius“ interesus, griebiasi kolektyvinių veiksmų, savo rèmëjų mobilizacijos, kuri gali igauti ir prievartos pobūdį ${ }^{4}$.

Institucinė politinès sistemos sąranga, kurioje dominuojančią vietą vaidina kitais valstybiniais institutais menkai apribota ir kontroliuojama aukščiausia vykdomoji valdžia, politiniam stabilumui pavojinga dèl dvieju svarbesnių priežasčių. Kartą išrinkti į tokią valdžią, ją atstovaujantys, gali siekti dar labiau didinti savo kompetencijų ribą ir, kas yra svarbu, siekti ją išlaikyti neribotą laiką. Tokia situacija gali provokuoti arba diktatūros įvedimą, arba visuomenės sukilimą. Antra vertus, politinejje sistemoje, kuriai būdingas ir susipriešinusios politinès konkurencijos tipas, aukščiausia vykdomoji valdžia tampa svarbiausiu politiniu ,prizu“. Jị laimèjusi politinė jẻga gali tikètis ne tik visiškai patenkinti ją remiančių grupių interesus, bet ir eliminuoti iš politinio žaidimo savo oponentus. Tokiu būdu galimybė politiniam kompromisui smarkiai sumažẻja, o konfrontacijos - išauga ${ }^{5}$ (Labiau difuzinèje sistemoje, kur aukščiausia vykdomoji politinè valdžia nẻra tokia įtakinga, egzistuoja palankesnes prielaidos svarbiausioms politinèms jẻgoms siekti kompromiso ir valdžios „pasidalijimo.“).

\footnotetext{
${ }^{3}$ Goldstone J., Ulfelder J., ,"How to Construct Stable Democracies“ The Washington Quarterly, vol. 28, Winter 2004/2005, p. 9-20. Beje, abu straipsnio autoriai dalyvavo igyvendinant projektą „Political Instability Task Force. Internal Wars and Failures of Governance".

${ }^{4}$ Ten pat, p. 15.

${ }^{5}$ Goldstone (3 išnaša) p. 16-17.
} 
Reikètų pastebèti, jog Ukrainos demokratijos nestabilumo problema vienu ar kitu aspektu pakankamai dažnai tapdavo mokslininku, tarp jų ir lietuviu, tyrinejjimo objektu. Nesiimsime plačiau jų aptarinèti. Trumpai apžvelgsime tik kelis tyrimus, daugiau dèmesio skirdami metodologinio pobūdžio problemoms. Grupè autoriu (V. Pigenko, Ch. R. Wise ir T. L. Brown) aptarinėdami Ukrainos demokratijos stabilumo problemą, o konkrečiau šalies politinio elito požiūrị i valdžiu (įstatymų leidžiamosios ir vykdomosios) atskyrimo klausimą, pastebëjo, jog politinės diskusijos dẻl institucinės sistemos sąrangos buvo veikiamos skirtingų ideologinių nuostatų bei skirtingos geopolitinės orientacijos $6.1996 \mathrm{~m}$. Konstitucijos priėmimo išvakarèse politinès grupės, kurios pasisakẻ už stipraus parlamento idejją, kartu siekẻ išsaugoti socialistinės - planinės ekonomikos pagrindus ir kaip galima intensyviau plèsti ryšius su Rusija. Stiprios prezidentinės valdžios rèmëjai buvo už rinkos reformų gilinimą ir provakarietišką orientaciją. Pirmoji tendencija buvo labiau būdinga Ukrainos politinei „,kairei“ (socialistams ir komunistams), o antroji dešinei - vadinamiesiems "nacional-demokratams“. Anot tyrimo autoriu, ideologinių ir geopolitinių orientacijų nesuderinamumas susitarimus dèl institucinès sąrangos daro politiniame elite nestabiliais, o tai žada naują konfliktą, ypatingai tuo atveju, jei „laimètojas“ bandytu pakeisti institucinio „žaidimo“" taisykles. Lietuvių tyrinètoja Ž. Satūnienè, analizavusi stabilios, konsoliduotos demokratijos įsitvirtinimo Ukrainoje prielaidas, apskritai padaré išvadą, jog „politinio režimo nepastovumas (ir demokratija, ir autoritarizmas)“ yra ",normali“" ilgalaikè, taigi, galima sakyti, konsoliduota posovietinės Ukrainos politinio režimo forma “. ${ }^{7}$ Vienas svarbesnių argumentu, kuriuo remdamasi autore padare tokią išvadą, buvo tas, jog dèl ypatingo verslo ir politiniu grupių interesu suaugimo, Ukrainos valdžios elito struktūroje dominuos kuri nors viena „oligarchine““ grupè, kurios pagrindinis tikslas yra maksimizuoti savo naudą, o tokia situacija skatins įtampą bei prieštaravimą, o tai gali reikšti tik politinès sistemos nestabilumą..

Manytume, jog abu aukščiau minèti tyrimai mums gali būti naudingi tuo, jog suteikia papildomu argumentų „supriešintos politinés konkurencijos" modeliui. Taigi šiame tekste remiantis Jack Golsdtone ir Jay Ulfelder pasiūlytu kriteriju pagalba bus aptariama Ukrainos politinio režimo dinamika po Oranžinės revoliucijos. Nuostata iš esmès, kuria remiasi analizè - Ukrainos demokratiniam režimui dar pakankamai ilgą laiką bus būdingas politinis nestabilumas.

\footnotetext{
${ }^{6}$ Pigenko V., Wise Ch., Brown T. L., „Elite Attitudes and Democratic Stability: Analysing Legislators' Attitudes towards the Separation of Powers in Ukraine" , Europe - Asia Studies, vol.54, no. 1, 2002, p. 92.

${ }^{7}$ Šatūnienė Ž., „Nepastovus posovietinès Ukrainos politinis režimas ir demokratijos konsolidavimo perspektyvos", Politologija, nr. 1, 2006, p. 62-63.
} 


\section{Politinès konkurencijos pobūdis}

Koks politinės konkurencijos modelis būdingas Ukrainai? Artëjant 2006 $\mathrm{m}$. kovo mèn. Rados rinkimams šalies politinëje ir partinëje sistemoje išryškëjo trys svarbiausios politinès jègos: tai proprezidentine - valdžios partija, tiksliau kelių partiju koalicija, Mūsų Ukraina, vadovaujama paties prezidento V. Juščenkos, „Regionu partija“, kurios lyderis V. Janukovičius bei Julijos Timošenko blokas (Po vadinamuju ",oranžinių" jègų skilimo $2005 \mathrm{~m}$. rudenį tapo galutinai aišku, jog Timšenkos ir Juščenkos vadovaujamos partijos rinkimuose dalyvaus atskirai.).

Dar iki 2006 m. Rados rinkimų kai kurie Ukrainos analitikai teigè, jog pagrindiniu iššūkiu bei grèsme šalies politinei sistemai, jos stabilumui gali tapti vis stiprëjantis „,visuomeninis ir politinis šalies skilimas, kuris įvyko dar prezidento rinkimų metu". Sociologiniai tyrimai ( $2005 \mathrm{~m}$. pavasaris) rodè, kad pakankamai didelè ukrainiečių dalis fiksuoja tokio pobūdžio skilimą. Pasak apklausu, apie $44 \%$ Ukrainos gyventojų teigè, jog šalyje egzistuoja tokio pobūdžio skilimas, $40 \%$ apklaustuju tai neigè. Net $82 \%$ rinkèjų, kurie balsavo už Juščenką prezidento rinkimuose, teige, jog šalis vystosi "teisinga kryptimi“, tačiau tik $17 \%$ balsavusių už Janukovičių tam pritarè'. Žinoma, galima manyti, jog "skilimo“ suvokimas visuomenejje pirmiausia buvo paveiktas prezidento rinkimų kompanijos, kurios atsiminimai dar buvo pakankamai stiprūs. Tačiau pabrèžtina ir ta aplinkybė, jog ir vèliau atliktos apklausos rodè tam tikrą įtampą visuomenëje, konkrečiai šalies "rytų" ir „vakaru“" skalëje. 2005 m. pabaigoje (lapkričio mėn.), Kijevo Tarptautinio sociologijos instituto atliktoje apklausoje $35 \%$ respondentu pritare teiginiui, jog tarp rytų ir vakarų egzistuoja įtampa, o $49 \%$ su tokiu teiginiu nesutiko (Beje, Ukrainos rytiniuose rajonuose net 54 $\%$ pritare tokiam teiginiui, o vakariniuose priešingai - dauguma tam prieštaravo. $)^{9}$. Akivaizdūs skirtumai egzistavo atskirų Ukrainos regionų gyventojų geopolitikos orientacijose. Iš $2005 \mathrm{~m}$. atliktų apklausų aiškèjo, jog šalies vakariniai rajonai vienareikšmiškai pasisakẻ už santykių su Europos Sajungą plètrą $(60,7 \%)$, rytinį šalies užsienio politikos vektorių - santykius su Rusija ir NVS šalimis - atitinkamai rėmé 7,9 \% ir 6,6 \% apklaustujų. Tuo tarpu Ukrainos rytuose dominavo visiškai priešingos tendencijos. Čia santykius su Rusija ir NVS šalimis prioritetiniais laikė 56,7 \% ir 16,2 \% apklaustuju, o už santykių su

\footnotetext{
${ }^{8}$ Якименко Ю., Литвиненко А., Жданов И., „Кто и за что, с кем и против кого? Партии Украины за год до выборов“, http://www.zn.ua, 200504 02. Beje, 2005 m. pabaigoje atliktos apklausos rodè, jog net 50 \% ukrainiečių mano, jog jų gyvenimo sąlygos, išrinkus Juščenką prezidentu, pablogèjo, tik 11,5\% mano, kad pagerejo. Žr. „Почти половина украйнцев щитает, что при Ющенко они стали жить хуже“, www. rosbalt.ru, 20051020.
}

${ }^{9}$ Moshes (1 išnaša) p. 22. 


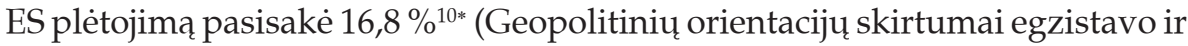
tarp pietų bei centro regionų. Pirmieji labiau rinkosi rytų orientaciją, o antrieji rinkosi labiau vakarų. Tiesa, atotrūkiai čia nebuvo tokie ryškūs.) ${ }^{11}$.

Prieš rinkimus kai kurie Ukrainos politologai prognozavo, jog $2006 \mathrm{~m}$. Rados rinkimai gali tik dar labiau plèsti egzistuojančias regionų ir kultūros takoskyras. Politinès partijos, siekdamos mobilizuoti "savo" rinkëjus, gali bandyti išnaudoti egzistuojančius kultūros ir regionų skirtumus bei priešiškumus. Regioninių, kultūrinių skirtumu (pvz., rusų kalbos kaip valstybinès klausimas, kuris aktualus „rytams“, bet nèra svarbus vakarams) eskalavimas rinkimų kampanijos metu galëjo tik dar labiau paryškinti šalies „,skilimą" pagal rytų ir vakaru perskyrą. Taip pat manyta, jog rinkimuose iš esmès dominuos "konfliktinès temos". O tai dar labiau komplikuos santykius tarp svarbiausiu Ukrainos politinių partijų. Prognozuota, jog "oranžinès“ stovyklos atstovai bandys „atskleisti“" buvusio režimo įvairius nusikaltimus, eskaluos kovos su oligarchija, įvairias korupcijos temas. Opozicija, ,"mèlynieji“ , turètų išnaudoti „politinių represijų“ klausimą tiek prieš pavienius asmenis, tiek prieš atskirus regionus, kurie palaikè opoziciją prezidento rinkimu metu. Neatmesta galimybè, jog „Regionu partija“ rinkimų kampanijos metu gali aktyviai naudoti rusų kalbos, kaip pripažintos antros valstybinès kalbos, klausimu, būtinybe plètoti geresnius santykius su Rusija, o gal net imsis eskaluoti antivakarietišką ar antiamerikietišką nuotaiką ${ }^{12}$. Viešai rodomas priešiškumas tarp politiniu jègų rinkimų metu turètų įtakoti ir politinių kompromisų sudarymo galimybę po rinkimų. Juolab, jog daugelis priešrinkiminių prognozių liudijo, jog nè viena politine jẻga neiškovos absoliučios pergalès ir bus priversta ieškoti sąjungininkų.

Reikètų pažymèti, jog anaiptol ne visi mokslininkų spejjimai dèl rinkimų raidos pasiteisino. Rinkimu rezultatai liudijo, jog Ukrainos politinė ir partinè sistema įgauna labiau struktūruotą pobūdį. Rinkimus laimėjo V. Janukovičiaus vadovaujama "Regionu partija“, surinkusi šiek tiek daugiau nei 32 \% rinkëju balsu ir iškovojusi 186 vietas parlamente. Antras liko J. Timošenko blokas (22,27 \% ir 129 vietos), tik trečias liko prezidento V. Juščenkos remiamas „Mūsu Ukraina“ blokas (13,94 \%, 81 vieta) Trijų procentų barjerą dar įveikè „,Socialistų“ (5,67 \%, 33 vietos) bei „Komunistu“ partijos (3,66 \%, 21 vieta.) Tokie rinkimu

\footnotetext{
${ }^{10}$ Pastebimas buvo ir paramos šalies ,,daugiavektoriškumui“ arba kitaip tariant balansavimo tarp Vakarų ir Rytų politikai mažejjimas (žr. Евгений Головаха: „Борбу между „правыми“ и „левыми“ некомпетентные политики превратили в войну между региональными и языковыми групами“, http://www.grani.kiev.ua, 200608 06.). O dar 2003 m. ,daugiavektoriškumą“ rẻmė $38 \%$ rytų ir pietų regionų gyventojų (atitinkamai už „vakarų“ krypti pasisakè $7 \%$, už „rytuc“ - $22 \%$ ), 39 \% centro (čia už „vakarų“ krypti pasisakè $11 \%$, o rytų - $13 \%$ gyventoju), 20 \% vakarų (populiariausia čia buvo ,provakarietiška“ orientacija - 39\%, ,rytų“ vektorių rėmė 5 \%). Žr. Konieczna J., „Mędzy Wschodem i Zachodem“, Fundacja Batoriego, Warszawa, 2004, p. 8-9.

${ }^{11}$ Plg. ,Ukraine's European Integration in Popular Perceptions“", National Security and Defence, no. 7, 2005, p. 43-44.

12 Якименко Ю., Литвиненко А., Жданов И., „Кто и за что, с кем и против кого? Партии Украины за год до выборов“, http://www.zn.ua, 20050402.
} 
rezultatai ir politinių jëgų santykis naujojoje Radoje rodè, jog „oranžinės jėgos“ (Timošenkos blokas, „Mūsų Ukraina“ ir A. Morozo vadovaujami socialistai) turi visas galimybes parlamente suformuoti pakankamai stabilią daugumos koaliciją, kuri, remiantis nauja Konstitucija, pateiks prezidentui vyriausybès vadovo kandidatūrą. Kai kurie analitikai, vertindami gerą Timošenkos bloko pasirodymą, padarè išvadą, jog Ukrainoje apskritai formuojasi prielaidos naujam „centro“" politiniam blokui (Timošenkos politinè partija daugiausia balsu gavo centriniuose šalies rajonuose.) $\mathrm{O}$ toks blokas galètų sumažinti įtampą egzistuojančią tarp rytų-pietų ir centro-vakarų regionų ${ }^{13}$. Tiesa, čia pat reikètų pažymèti, jog, mūsų manymu, gerus rezultatus Timošenkos blokui garantavo ne tiek jos politinė programa, kuri nukreipta į šalies „,suvienijimą“, bet labiau jos asmeninè charizma, iš esmès populistiniai pažadai, o gal ir "radikali“ jos partijos opozicinè laikysena (Po 2005 m. rudenį Timošenko pasitraukè į opoziciją Prezidentui Juščenkai, kartu aštriai kritikuodama „oligarchinę“ "Regionu partiją“.).

Antra vertus, visgi reikètų pastebėti, jog kai kurios politologų prognozès pasitvirtino. Apibendrindami 2006 m. kovo mèn. Rados rinkimus, Ukrainos politikos ekspertai darè išvadą, jog tradicinės politinès perskyros, kurios buvo būdingos Ukrainos politinei sistemai (kairè-dešinè, „naciol-demokratai“"-,rusofilai“") silpnejja, tačiau aktuali išliko rytų ir vakarų takoskyra ${ }^{14}$. Pagrindžiant tokią išvadą, buvo nurodoma, jog elektoratas paprastai buvo mobilizuojamas regioniniu ir kalbos arba, kitais žodžiais tariant, teritoriniu ir kultūriniu pagrindu. Tokias išvadas iš esmès patvirtina rinkimų rezultatai ${ }^{15}$. "Regionų partija“ laimëjo dešimtyje pietinių ir rytinių šalies regionų (daugiausia balsų gavo ir didžiausiu santykiu Janukovičiaus partija laimėjo Donecko, Luhansko srityje bei Sevastopolio mieste). Iš viso už „Regionu partiją“ balsavo šiek tiek daugiau nei $8,1 \mathrm{mln}$. rinkèjų $\mathrm{u}^{16^{*}}$. J. Timšenkos blokas laimèjo 14 sričių, kurias paprastai tyrinètojai priskiria šalies centrui. Iš viso už Timošenkos partiją balsavo 5,6 $\mathrm{mln}$. rinkëjų. Daugiausia balsų ši politinè jèga gavo Kijevo bei Volynès srityse ir šalies sostinėje Kijeve. Prezidento Juščenkos „Mūsų Ukraina“ laimejjo tik trijose vakarinése šalies srityse: Ivano-Frankivske, Lvive bei Užkarpatëje (Iš viso „proprezidentinę“" partiją parėmẻ šiek tiek daugiau nei 3,5 mln. rinkẻju.).

\footnotetext{
${ }^{13}$ Moshes (1 išnaša) p. 22-23.

14 „Евгений Головаха: „Борбу между „правыми“ и „левыми“ некомпетентные политики превратили в войну между региональными и языковыми групами“, http://www.grani.kiev.ua, 20060806.

${ }_{15}$ Žr. http:/ / www.cvk.gov.ua/vnd2006/w6p001.html.

16* Tiesa, yra mokslininkų, kurie teigia, jog rytų Ukrainos „politinis subjektyviškumas“ yra smarkiai perdedamas. Tokią prielaidą jie grindžia rytų Ukrainos politinio elito elgesiu po Oranžinès revoliucijos. Bent jau dalis rytų Ukrainos politinio elito ėmė siekti kompromiso su naujaja „oranžine“ vyriausybe (Dalis politikų ir verslo elito, t. y. tie, kurie aktyviai dirbo „Regionų partijoje“, perėjo i „,oranžinès“ stovyklos pusę.). Tokia laikysena buvo įtakota tos aplinkybès, jog svarbiausiu politikos subjektu šalies rytuose yra stambus verslas, kuris apskritai nusiteikęs siekti „konstruktyvaus“ dialogo su bet kokia valdžia. Tuo remiantis netgi buvo daroma išvada, jog jis iš principo negali tapti rimta politine opozicija. Plačiau žr. „Доклад Института национальной стратегии Украины“ (С. Белковский, К. Бондаренко, В. Вакарюк, Е. Курмашов, А. Мушак). Новый политический сезон: выборы-2006 и продолжение оранжевой революции“, Агентство политических новостей, http://www.apn.ru, 20050824.
} 
Toks regioninis ir kultūrinis elektorato bei partinės sistemos skilimas sunkino politinio kompromiso galimybę, o galimą politinę koaliciją darẻ nestabilią, trumpalaike.

Svarbu pažymèti ir dar vieną politinès ir partinès sistemos aspektą. Takoskyros egzistavo ne tik tarp „,oranžinių“ politiniu jègų ir ",mèlynujų“- „Regionu partijos", bet ir pačioje vadinamoje demokratinëje koalicijoje. Apskritai "oranžinę" stovyklą politinės ideologijos požiūriu sudarẻ pakankamai margos jëgos: nuo socialistų iki „nacionaldemokratų“. Nors ir galima būtų teigti, jog tas jègas vienijo Oranžinės revoliucijos „paveldo“ - politinės sistemos demokratizacijos bei reformų - siekis, tačiau konkretų reformų turini jos ịsivaizdavo skirtingai, o dažnai ir priešingai. Anaiptol nevienodi buvo ir užsienio politikos bei geopolitinės orientacijos prioritetai. Norint išlaikyti tokią koaliciją vieningą, svarbus tampa jos lyderio ir jo autoriteto klausimas. Neformaliu demokratinès koalicijos lyderiu galima buvo laikyti Prezidentą Juščenką. Tačiau 2006 m. kovo mèn. jis jau nebegalejo atlikti lyderio bei tarpininko vaidmeni, kuris derina visų oranžiniu jègų interesus. Manytume, jog tai atsitiko dèl kelių priežasčių. Pirma, Ukrainos Prezidento reitingai po revoliucijos ėmė nepaliaujamai kristi (Juščenkos populiarumo kritimas pastebimas jau nuo $2005 \mathrm{~m}$. pradžios, tuo pat metu pažymimas Timošenkos reitingų augimas. Apklausų duomenimis, nuo $2005 \mathrm{~m}$. vasario iki birželio Juščenkos reitingas sumažèjo nuo $37,5 \%$ iki $20 \%$, o Timošenkos pakilo - nuo $10 \%$ iki 17,3 \% ${ }^{17}$ ) Taigi Juščenka „oranžinių“ stovykloje įsigijo stiprų konkurentą. Juo tapo J. Timošenko, kurios partija, kaip jau pastebëjome, rinkimuose finišavo antroji, o prezidento V. Juščenkos „Mūsu Ukraina“ tebuvo trečia. Apskritai tariant, Timošenko save apibūdino kaip aktyvią „paprastų žmonių“ interesu gynėją, kovojančią su oligarchais bei Rusijos piktais kẻslais. Nuo 2006 m. pradžios prasidejjusi Konstitucinè reforma apribojo ir tuo pačiu pagrindiniu politinių veikejju požiūriu susilpnino prezidento galias. Kartu išaugo Rados pirmininko bei vyriausybės vadovo postu prestižas ir ịtaka. Ši aplinkybe "oranžinių“ stovykloje tik dar labiau padidino konkurenciją ir varžybas, kas juos turètu užimti. Realiausiu pretendentu, kuris užimtų ministro pirmininko postą, buvo Timošenko, tačiau toks įvykiu scenarijus nelabai tenkino Prezidentą.

Priminsime, jog nesutarimai tarp Oranžinės revoliucijos lyderių ir juos remiančių politinių struktūru prasidèjo dar $2005 \mathrm{~m}$. viduryje ${ }^{18}$, o rugsëjo mèn. Juščenkos ir Timošenko sajunga galutinai subyrëjo. Formaliai krizė įsiplieskẻ po to, kai Timošenko šalininkai apkaltino Prezidentui Juščenkai artimus politikus korupcija. Prezidentas nutarẻ atstatydinti Timošenko vyriausybę ir

\footnotetext{
${ }^{17}$ Cit. pagal Доклад Института национальной стратегии Украины (С. Белковский, К. Бондаренко, В. Вакарюк, Е. Курмашов, А. Мушак) „Новый политический сезон: выборы-2006 и продолжение оранжевой революции“, Агентство политических новостей, http://www.apn.ru, 20050824.

${ }^{18}$ Politikos analitikai pažymėjo, jog jau 2005 m. vasarą „oranžinės“ stovyklos pagrindiniai veikèjai nebeslèpè vienas kitam priešiškumo ir nesikuklino tarpusavio konfliktų demonstruoti viešai. Доклад Института национальной стратегии Украины (С. Белковский, К. Бондаренко, В. Вакарюк, Е. Курмашов, А. Мушак) „Новый политический сезон: выборы-2006 и продолжение оранжевой революции“, Агентство политических новостей, http://www.apn.ru, 20050824.
} 
atsisveikinti su keliais savo politiniais bendražygiais. Tokiu būdu Timošenko politinis blokas perèjo i̇ opoziciją prezidentui. Ši aplinkybè tik dar labiau pagilino politinę krizę šalyje. Naujajį vyriausybės vadovą Jurijų Jechanurovą Rada patvirtino tik po to, kai jo kandidatūra parèmè „Regionų partija", vadovaujama Janukovičiaus. Siekdamas išbristi iš politinès krizès ir suformuoti vyriausybę, Juščenka pasirašė su Janukovičiumi susitarimą, kuriuo naujoji valdžia įsipareigojo teisiškai nepersekioti Janukovičiaus rẻmėjų. Toks paktas leido suformuoti vyriausybę, ir tuo pačiu laikinai stabilizavo situacija šalyje. Antra vertus, tokie neišvengiami politiniai „kompromisai“ pirmiausia „oranžinių“ elektorato tarpe skatino nusivylimą, didino įtampą bei konfliktiškumą "demokratinëje stovykloje“. Apskritai Timošenko stengėsi visaip išnaudoti Prezidento ir vyriausybės tariamą ar tikrą "kompromisiškumą", save pristatydama kaip bekompromsę, ,kietą" politikę. Ji aktyviai kritikavo dujų 2005 m. pabaigos susitarimą tarp Rusijos dujų monopolistès "Gazprom“ ir Ukrainos, o šį susitarimą parėmė Prezidentas bei premjeras. Teisingumo dèlei reikètų pasakyti, jog šis susitarimas daugelio užsienio ekspertų buvo vertinamas kaip neskaidrus, tačiau Timošenko jo anuliavimą ar bent jau peržiūrèjimą pavertẻ savo politikos tikslu. Kai yra tokia nepasitikëjimo ir net priešiškumo situacija, „oranžinės” koalicijos kūrimo klausimas tapo labai problematiškas. Tolesni, po 2006 m. rinkimų sekę įvykiai, šitokią prielaidą visiškai patvirtino. Derybos dèl koalicijos sudarymo užsitęsè. "Oranžinių" lyderiai niekaip nesugebejjo susitarti dèl svarbiausių valdžios postų. Derybas sunkino ta aplinkybė, jog Timošenko siekè sau išsaugoti vyriausybès vadovès postą, o „Mūsų Ukraina" bloke buvo pakankamai stiprios politinès jègos, kurios to posto Timošenko nenorèjo „atiduoti." Galiausiai pastangos sudaryti „oranžinių koaliciją“ žlugo, kai iš jos pasitraukè socialistai.

Tuoj po šių įvykių Radoje buvo paskelbta apie naujos ",antikrizinès“ koalicijos susidarymą į kurią įejo "Regionu partija“, socialistai ir komunistai. Ši koalicija Rados pirmininku išrinko socialistų lyderį A. Morozą, o prezidentui į ministro pirmininko postą pateikè V. Janukovičiaus kandidatūrą. Politinè krizė, kilusi po kovo mèn. Rados rinkimu, išsisprendè tik rugpjūčio mèn. pradžioje. Prezidentas Juščenka pateikẻ parlamentui tvirtinti V. Janukovičiu vyriausybės vadovu. Radoje susiformavo nauja koalicija („Regionų partija“, „Mūsų Ukraina“, „Socialistų partija“), kuri ir sudarè vyriausybę. Regionų partijai atiteko „ekonominių“" ministerijų blokas, prezidentas išsaugojo įtaką formuojant šalies saugumo bei užsienio politiką. Koalicijos nariai pasirašè prezidento inicijuotą „Universalą“ - dokumentą, kuriame apibrèžti Ukrainos vidaus bei užsienio politikos prioritetai (Tiesa, dokumentas įstatyminès galios neturejjo ir pasirašiusių niekaip rimčiau nesaistè. Timošenko bloko atstovai jo nepasirašè.). Po šių susitarimų buvo užbaigtas formuoti Konstitucinis Teismas. Tolesnè įvykių raidą parodè, jog politinis kompromisas tarp valdančios koalicijos ir prezidento buvo trumpalaikis.

Dar 2006 m. vasarą Ukrainos analitikai ėmė rašyti apie apie krizės tarp dvieju vykdomosios valdžios šaku - prezidento ir ministrų kabineto - neiš- 
vengiamumą ${ }^{19}$. Pradžioje konfliktai tarp Juščenkos ir Janukovičiaus kilo dèl kelių (užsienio reikalų ir gynybos) ministrų. Pagal Konstitucijoje užfiksuotą prezidento kvotą, šis turi teisę skirti į vyriausybę kelis ministrus. Iš esmès ginčas tarp dviejų aukščiausios vykdomosios valdžios atstovu - prezidento ir premjero - vyko dèl kompetencijos ribų nustatymo. Premjeras, apeliuodamas į vykstančią reformą, stengèsi savo kompetencijos ribas išplèsti, o prezidentas vèl apeliuodamas į reformą - išsaugoti. Santykius tarp prezidento ir premjero dar labiau paaštrino 2007 m. sausio mèn. Rados priimtas Ministrų kabineto įstatymas. Tokio įstatymo priėmimas buvo numatytas pagal vykstančią konstitucinę reformą. Antra vertus, Rada prièmè „Regionų partijos“ parengtą Ministrų kabineto įstatyma, kuris dar labiau išplètè vyriausybès vadovo funkcijas ir kartu susiaurino prezidento kompetencijos ribas. Svarbu atkreipti dėmesi i i tai, kaip įstatymas buvo priimtas. Prezidentas tokią įstatymo redakciją vetavo, tačiau „Regionu partija“ su ją parèmusiu Julijos Timošenko bloku prezidento veto iqveike ${ }^{20}$. Tokioje situacijoje svarbią arbitro funkciją, subalansuojančią politinę sistemą, turètų atlikti Konstitucinis Teismas, tačiau Ukrainoje jis iš politiniu ginčų sprendimo praktiškai buvo eliminuotas ${ }^{21}$.

Varžybos dèl galios tarp prezidento ir ministro pirmininko bei jị remiančios daugumos Radoje igavo vis didesnị pagreitị. Prezidentas reikalavo, jog Rada priimtų naują Ministrų kabineto įstatymo redakciją, kurioje būtų atsižvelgta i prezidento išsakytas pastabas, sustabdytų deputatų perëjimą iš vienos partijos į kitą, priimtų imperatyvinio mandato įstatymą Rados deputatams ${ }^{22 *}$. Rados dauguma, remianti Ministrą pirmininką, tokių prezidento reikalavimu neskubëjo vykdyti. Atrodo, jog valdančioje koalicijoje vis stiprëjo idejjos suformuoti Radoje konstitucinę daugumą ir skelbti prezidentui apkaltą. $2007 \mathrm{~m}$. pavasarį konfrontacija pasiekẻ kulminaciją. Matydamas, jog valdanti koalicija neatsisako minties suformuoti parlamente konstitucinę daugumą, Prezidentas Juščenko pareiškè, jog yra pasirengęs priimti nutarimą dẻl Rados paleidimo ir priešlaikinių rinkimų organizavimo (Už Rados paleidimą ir priešlaikinius rinkimus ypač aktyviai pasisakė J. Timošenko.). Balandžio pradžioje Rada buvo paleista, šalyje turëjo įvykti nauji parlamento rinkimai. Reikètų pažymèti, jog „kelias” ic rinkimus nebuvo paprastas. Laikotarpis nuo 2007 m. pavasario iki rudens, kada spalio mèn. surengti rinkimai į Radą, buvo kupinas įtampos.

\footnotetext{
19 „Эксперты: „Оранжевые“ министры не сработаются с Януковичем“, www.Korrespondent.net 2006 0822.

${ }^{20}$ Plačiau apie Ministrų kabineto įstatymo redakcijų skirtumus žr. Ведерникова И., „Кабмин в законе“, http://www.zerkalo-nedeli.com/op/show/612/54393/, no. 33, 200609 02-08.

${ }^{21}$ "Will democracy survive in Ukraine? What the experts say", http://www.icps.com.ua, 2007 0212 .

${ }^{22 *}$ Beje, ịstatymą dèl imperatyvinio mandato kritiškai įvertino Europos Tarybos ekspertai. Venecijos komisija konstatavo, kad Europos demokratinės valstybės remiasi išimtinai laisvo tautos atstovo mandato idejja. Imperatyvinis mandatas, kai kurių Ukrainos politikų manymu, turètu atgrasyti deputatus nuo perèjimo iš vienos frakcijos į kitą. Frakcijas pakeitęs deputatas praranda savo mandatą (Beje, imperatyvinio mandato praktika egzistuoja Indijoje, Nigerijoje, P. Afrikoje, Kuboje, Vietname).
} 
Būdingas to laikotarpio Ukrainos politikos bruožas buvo ne tik konfrontacija tarp įstatymų leidžiamosios ir vykdomosios (prezidento), tarp vyriausybès ir prezidento, tarp įvairių valstybès pareigūnu, politinių partijų bei atskirų politiku, bet ir pagrindiniu politinių jègų pastangos mobilizuoti savo rèmëjus kolektyviniams veiksmams. Šalies sostinèje vèl èmè dygti palapinių miesteliai, iš įvairių regionų į mitingus vežami žmonès. Tiesa, prievartos proveržių pavyko išvengti.

\section{2007 m. Rados rinkimai: i susitaikymą ar ị dar didesnị susipriešinimą?}

Formaliai 2007 m. Rados rinkimus laimèjo „Regionu partija“, surinkusi $2 \%$ daugiau rinkëjų balsų nei 2006 m. Jei palygintume absoliučius skaičius, tai pastebètume, jog rinkèjuc parama „Regionu partijai“ šiek tiek sumažèjo. Jei 2006 m. už partiją balsavo 8148745 rinkẻjai, tai 2007 m. - 8013 918. Antra vertus, reikètų pastebėti, jog partija išsaugojo pirmavimą tradicinėse, rytinèse ir pietinėse Ukrainos srityse. Be to, „Regionu partijai“ pasisekẻ šiek tiek padidinti savo rèmëjų skaičių centrinëje ir net vakarinejje Ukrainos dalyje (,Regionu partija" planavo gauti 5-10\% rinkejjų daugiau. Tačiau ne visose srityse tokie skaičiai buvo pasiekti.) İdomu ir tai, jog rinkejjų parama "Regionų partijai“ bene labiausiai sumažèjo rytiniuose šalies rajonuose - Donecke partija neteko 130,6 tūkst. balsų, Luhansko - 70,6 tūkst., Charkivo - 106,5 tūkst. Tokie rezultatai lèmè tai, jog Radoje „Regionų partija“ iškovojo mažiau vietų - 175 vietoj turètų $185^{23}$.

J. Timošenko blokas gavo 30,7 \% rinkëjų balsu, taip padidindamas savo rèmëjuc gretas 1,5 mln. (2006 m. už bloką balsavo 5 652 876, o 2007 m. 7162174 rinkejjų.) 2007 m. Rados rinkimuose Timošenko partija laimëjo 16 sričių (2006 m. pergalę pasiekẻ 14 sričių.). 2007 m. rinkimuose nugalèta Ivano-Frankivsko ir Lvivo srityse (2006 m. šiose srityse laimẻjo „Mūsų Ukraina“ partijų susivienijimas.). Apskritai politikos analitikai pastebi, jog Timošenko blokas sugebejjo visose Ukrainos srityse gauti šiek tiek daugiau rinkëjų balsų nei ankstesniuose rinkimuose. Visgi daugiausia Timošenko partija „prisidèjo“ balsų vakarinèse šalies srityse: Ivano-Frankivsko, Lvivo, Rivno, Ternopolio. Minètose srityse, jei lygintume su 2006 m. rezultatais, „papildomai“ gauta nuo 15 iki 20 \% rinkẻju balsų (Daugiausia dèl partijos „Mūsų Ukraina“ sąskaitos). Kaip ir buvusiuose rinkimuose, tai sunkiausia Timošenko sekèsi pietiniuose ir rytiniuose regionuose (Kryme, Donecke, Luhanske.)

Už koaliciją „Mūsų Ukraina - Liaudies savigyna“ balsavo 3,3 mln. rinkèju, o tai reiškia, kad prezidento aktyviai palaikyta politinè jèga surinko

\footnotetext{
${ }^{23}$ Николаенко Т., „Где Янукович потерял 300 тысяч, а Тимошенко получила 1,5 миллиона“, Украинская правда, http://www.pravda.com.ua/ru/news/2007/10/8/65005.htm, 20071008.
} 
238 tūkst. balsų mažiau nei buvusiuose rinkimuose. Laimėta tik vienoje srityjeUžkarpatėje. Bloko rodikliai „suprastëjo“ 12 sričių. Tačiau, kaip ir buvusiuose Rados rinkimuose, "oranžinès" jẻgos (jas kartu sudëjus) gavo daugiau balsu nei „Regionu partija“. Turint galvoje, kad A. Morozo vadovaujami socialistai į Radą nepateko, tai bent jau formaliai „oranžinių“ koalicija turi geresnes galimybes teikti Ministro Pirmininko kandidatūra.

Tokie rinkimų rezultatai leidžia daryti kelias išvadas. Pirma, manytume, jog „regionalizmas" vaidina ir toliau vaidins svarbų vaidmenį Ukrainos politikoje. Nacionalinių rinkimų (prezidento ar parlamento) eiga ir rezultatai liudija, jog skirtingi regionai remia skirtingas politines jègas, paprastai vienas su kita konfrontuojančias. Kultūrinès ir regioninès atskirtys, skirtingos geopolitinès gravitacijos, būdingos šalies „vakarams" ir "rytams", ir toliau bus svarbiu elektoratą mobilizuojančiu veiksniu. Tokia poliarizacija ir toliau darys politinę konkurenciją kupiną įtampos ir priešiškumo. Ši aplinkybė sunkina politiniu susitarimų bei koaliciju sudarymo galimybes. Todèl politinis nestabilumas išlieka vienu svarbiausių Ukrainos politinès sistemos bruožu.

\section{Politinès partijos - „parapijiniai“ politiniai žaidèjai}

Daugelis Ukrainos politologų negaili piktų žodžių savo šalies politinėms partijoms. Dažnai pastebima, jog šalies politinėms partijoms trūksta ideologinio apibrèžtumo, jos nèra "griežtai disciplinuotos" bei suskirstytos pagal hierarchiją. Jose vis dar didelį vaidmenį vadina lyderio asmenybè, o tarp partijos eilinių narių ir partinio elito „egzistuojančios ryškios prarajos “24. Jei ir manytume, jog kai kurie tokie teiginiai nèra pakankamai tikslūs, visgi dèl kitu tektų sutikti. Ukrainos politinių partiju , griežta partine“" disciplina yra aiškiai perdèta. Net ir didžiosios partijos susiduria su tam tikra vidine "fronda“" (pvz., Iš Timošenko bloko neseniai pasitraukẻ keletas įtakingu partiečių, kurie įsteigė "Laisvujų demokratų partiją". Daug rašoma apie trintis "Regionų partijoje" tarp dvieju įtakingiausiu šios politinès organizacijos grupių ir ju neformaliu lyderių - Janukovičiaus ir verslininko Achmetovo.).

Antra vertus, pastebejjimai apie prarają tarp partinio elito ir eilinių narių, apie partinio elito „uždarumą", manytume, yra pakankamai svarbūs. Anot tyrinėtoju, partinę politinę karjerą padaryti lengviau, kai pereinama iš vienos partijos i kitą, o ne vienos partijos viduje. Beje, „politinė krizè" 2007 m. tarp prezidento ir Rados kilo tuomet, kai dalis deputatu, opozicijos nariu, prisijungè prie parlamentinės daugumos (Tokios pat tendencijos būdingos ir renkamų vietinių valdžios organų deputatams. Jų ,judèjimą“ turëjo sustabdyti „imperatyvinio mandato" vietos deputatams priemimas.). Kokiam nors partiniam

\footnotetext{
${ }^{24}$ Олещук П., „Политические партии современной Украины: между клановой системой и феодальным образованием“, Украинская правда, http://www.pravda.com.ua/ru/, 20071010.
} 
veikëjui pakeitus partinę priklausomybę, paprastai yra garantuojama pakankamai aukšta vieta naujojoje partinëje nomenklatūroje. Veikla pirminėse partinėse struktūrose dažniausiai negarantuoja jokios partinès karjeros galimybės ${ }^{25}$.

Politiniu partijų uždarumą bei vadinamają oligarchiją lemia tai, jog jose dominuojantis vaidmuo tenka finansiniams rẻmejams, kurie kontroliuoja finansinius partijos srautus ${ }^{26}$. Partinejje hierarchijoje laipteliu žemiau stovi pagrindinių partijos finansininkų klientai, kurie savarankiško politinio vaidmens nevaidina. Neturint įtakingo "globejo" ar nedisponuojant finansiniais resursais, daryti partinę karjerą labai sudètinga. Eiliniai partijos nariai, dažniausiai pasyvūs, yra šios piramidès apačioje $\mathrm{e}^{27}$.

Politinès programos ar ideologinės nuostatos partiju identifikacijoje nèra reikšmingos. Jos tẻra tik tam tikra širma, kurios pagalba pridengiamas hierarchinis bei oligarchinis partiju pobūdis. Iš esmès politinès šalies partijos rungtyniauja, kuri pasiūlys rinkejjams efektingesnę ir jo aukštus lūkesčius atitinkančią socialinę ir ekonominę programą. Tiesa, dažnai nesirūpinama paaiškinti, kaip tokios programos bus igyvendinamos. $2007 \mathrm{~m}$. Rados rinkimai šiuo požiūriu būtu geras pavyzdys. „Regionų partija“ save apibūdino kaip jẻgą, galinčią užtikrinti gerus santykius su Rusija, taip pat turëjusia susitarti dèl mažesnių dujų vartojimo kainu, o Timošenko blokas aktyviai kẻlè indèlių grąžinimo klausimą.

Apibendrinant galima teigti, jog svarbiausios politinės Ukrainos partijos turi įtakingus verslo rẻmëjus. Jei šių ekonominiai interesai nesutampa su galimybe partijoms susitarti, tai siekti kompromiso sekasi sunkiai. Antra vertus, vis mažejjant politinės ideologijos veiksniui partinëje identifikacijoje, didejja kultūrinio ir regioninio faktoriaus įtaka. Rados rinkimuose „Regionu partija“ jau "tradiciškai“ išsiskyrẻ tuo, jog kèlè rusų kalbos, kaip būsiančios antros valstybinès kalbos, įvedimo klausimą bei pasisakè už neutralu šalies statusą (Pažymėsime, jog nei „oranžinès“ jègos, nei „Regionų partija“ užsienio politikos tarp prioritetu rinkimų kampanijos metu neakcentavo).

\section{Konstitucinès reformos vingiai: atgal ị prezidentinị valdymą?}

Trumpai priminsime, kad nuo $2006 \mathrm{~m}$. sausio mėnesio Ukrainoje įsigaliojo "konstitucinė reforma“. Joje numatyta pailginti Rados veikimo laiką nuo 4 metų iki 5 metú. Reforma padidino politinių partijų vaidmeni politinejje sistemoje. Dabar tiek rinkimai į vietos valdžios organus, tiek į bendrus naci-

\footnotetext{
$\overline{{ }^{25} \text { Олещук (21 išnaša). }}$

${ }^{26}$ Apie kai kurių Ukrainos politinių partijų finansinius rėmėjus žr. Данилов А.,, „Коалиция „оранжевых“ партий: террариум единомышленников“, http:/www.ura-inform.com/archive/?/2006/02/15/ /60503, 20060215.

${ }^{27}$ Олещук (21 išnaša).
} 
onalinius rinkimus vykdomi pagal proporcinę sistemą (Pasisakyta už imperatyvinio mandato įvedimą, o tai reiškia, kad deputatai, išrinkti pagal partini sąrašą, praranda mandatą, jei per kadenciją pereina iš vienos parlamentinès frakcijos i kitą.). Daugumą parlamente iškovojusi politinė partija ar partiju koalicija teikia prezidentui vyriausybès vadovo kandidatūrą. Prezidentas išsaugojo pakankamai svarbias galias: jis turi teisę paleisti parlamentą, jei šis per 60 dienų nuo savo darbo pradžios nesugeba suformuoti vyriausybės; prezidentas turi prerogatyvą skirti užsienio ir gynybos ministrus, yra atsakingas už šalies užsienio politiką. Tiesa, prezidentas nebegali skirti vyriausybės nariu ar jų atšaukti be parlamento pritarimo. Taip pat nebeturi veto teisès konstitucijos pataisoms. Antra vertus, reformoje nebuvo pakankamai aiškiai aptartos prezidento ir vyriausybės vadovo kompetenciju ribos, apibrèžta opozicijos padètis parlamente. Kitaip tariant, nebuvo formalizuotos taisyklès, kaip bus sprendžiami konfliktai tarp svarbiausių valdžios šakų - prezidento ir įstatymų leidžiamosios valdžios, tarp prezidento ir vyriausybės, kokias garantijas gauna opozicijoje likusios politinès jẻgos.

Netgi kritiškai Ukrainos atžvilgiu nusiteikę politikos analitikai buvo priversti pripažinti, jog konstitucinẻ reforma žymiai pakeite šalies politinę, institucinę sistemą - Ukraina atsisakè stipraus prezidentinio valdymo, būdingo NVS erdvès šalims ${ }^{28}$. Tokie pokyčiai turèjo būti svarbus saugiklis, apsaugantis politinę sistemą nuo autoritarizmo. Prezidento galių perdavimas ministrui pirmininkui, turèjo sumažinti politinès konkurencijos intensyvumą bei priešiškumą dèl to, kas bus šalies prezidentu. Formuojama politinė sistema turèjo būti grindžiama balansu tarp "pakankamai stipraus prezidento“ ir "pakankamai stipraus ministro pirmininko". Kartu buvo pripažįstama, jog tokia sistema turi ir tam tikru pavojų. Šalis gali išgyventi permanentišką politinę krizę ir nestabilumą, jei skirtingas politines jègas atstovaujantis prezidentas bei vyriausybès vadovas nesugeba pasiekti kompromiso. Politinį procesą Ukrainoje komplikavo ta aplinkybė, jog nebuvo aiškių taisykliu, kaip praktikoje turètų būti sprendžiami konfliktai tarp dviejų vykdomosios valdžios šakų. Antra vertus, reikètų turèti galvoje, jog dèl konstitucinès reformos principu buvo sutarta po daugybės konfrontacijų tarp politinio elito ir juos remiančių visuomenès grupių ir po daugybès sąlygų. Todèl visiškai suprantama, kad dèl daugelio svarbių dalykų nebuvo iki galo sutarta iš esmès. Nebuvo aiškiai aptartas centrinès ir vietos valdžių santykis. Konstitucijoje neaprašyta procedūra, kaip skirti vietos administracijų vadovus. Teigiama, kad ju kandidatūras pateikia Ministrų kabinetas, o tvirtina Prezidentas, tačiau nieko nekalbama apie toki atveji, kada prezidentas kandidatūros nepatvirtina. Taigi prezidentas lyg ir gali pakankamai ilgą laiką neskirti vadovo, tačiau tai gali kelti grèsmę valstybès valdymo efektyvumui ${ }^{29}$. Apibendrinant galima teigti, jog politinė reforma

\footnotetext{
28 „Чем грозит Украине партийный хаос, интервю директора Российского института стратегических исследований Е Кожохина“, http://www.izvestia.ru/world/article3076313, 20060217.

29 „Эксперт: Необходим переход к новой стадии Конституционной реформы““ http://www.korespondent. net, 20061121.
} 
turëjo kompromisinị pobūdị, kuris leido išvengti ilgos politinės krizės $2004 \mathrm{~m}$. pabaigoje $-2005 \mathrm{~m}$. pradžioje, tačiau nesprendẻ daugelio valstybei gyvybiškai svarbiu institucinio pobūdžio klausimų.

Todèl nenuostabu, jog, kai krizè baigèsi, pasigirdo reikalavimai Konstitucinę reformą peržiūrèti arba net jos iš viso atsisakyti. Tokie reikalavimai dažniau buvo išsakomi „oranžinių" stovyklos. „Oranžinių“ norą peržiūrèti konstitucinę reformą ir vèl iš esmès grị̌ti prie prezidentinès respublikos modelio galima nesunkiai paaiškinti. Prezidentui Juščenkai tai yra vienas iš būdų išsaugoti prestižą ir politinę įtaką, kuomet pasitikejimas juo visuomeneje vis labiau smuko (Timošenko, praradus valdžią, reforma taip pat nebuvo reikalinga.). „Oranžinių“ oponentai, atmesdami argumentus dèl konstitucinės reformos peržiūrëjimo, teigè, jog politinès reformos atsisakymas iškeltų Ukrainos prezidento rinkimu, t. y. Juščenkos legitimumo, klausimą. Priminsime, jog abiejų politinių jègu, Janukovičiaus ir Juščenkos, šalininkai sutare dẻl pakartotinu rinkimu idèjos po to, kai buvo sutarta dèl politinès reformos. Taigi buvo teigiama, kad tik reformos dèka Juščenka buvo išrinktas šalies prezidentu ${ }^{30}$.

„Regionu partijai“ suformavus daugumą Radoje, o Janukovičiui tapus ministru kabineto vadovu, tarp jo ir prezidento prasidejo matoma ir nematoma kova, kas igis daugiau įtakos ir galios - Prezidentas ar Vyriausybės vadovas. Tokia „,konkurencine kova“ apskritai neigiamai veikè valstybės valdymą. Priešiškumas tarp dviejų vykdomosios valdžios institucijų savo kulminaciją 2006 m. pabaigoje - 2007 m. pačioje pradžioje. Pagrindiniu nesutarimu klausimu tapo Ministru kabineto įstatymas. Beje, šis įstatymas Ukrainoje buvo „priiminejjamas" jau bent dešimt metú. Iš esmès jo priemimą blokavo ankstesnis šalies prezidentas Kučma. Be įstatymo jam buvo patogiau „vadovauti“ visai vykdomajai valdžiai (Atẻjus ị valdžią Juščenkos ir Timošenko tandemui iki 2005 m. rudens Ministru kabineto įstatymas taip pat nebuvo priimtas.). Ekspertu vertinimu, konstitucineje reformoje buvo nuostatos, kurias buvo galima skirtingai interpretuoti. Iš esmės tuo abi vykdomosios valdžios šakos ir naudojosi, vieną ar kitą nuostatą interpretuodama savo naudai ${ }^{31}$. Visai geru tokio „rungtyniavimo“" pavyzdžiu, kuris galëjo tik dar labiau sukomplikuoti valstybės valdymą, buvo prezidento aplinkos siūlomas idejos apie Nacionalinès saugumo tarybos įtakos išplètimą. Taip siekta sudaryti atsvarą Ministru kabineto kompetencijos augimui. Žinoma, tokio pobūdžio konfliktai turètu spręstis Konstituciniame Teisme. Tačiau šis buvo baigtas formuoti tik $2006 \mathrm{~m}$. viduryje ir arbitru ginčuose tarp atskirų vykdomosios valdžios šakų netapo.

Tuo tarpu diskusijos dèl konstitucinès reformos darėsi vis intensyvesnès ir karštesnès. Išryškëjo tendencija, jog dominuojančią padètį politinëje sistemoje užimančios politinès partijos skirtingai, o dažnai netgi visiškai priešingai, traktuoja konstitucinės reformos normas. Pastebèta, jog Ukrainoje nuo $1996 \mathrm{~m}$. Konstitucijos priėmimo ir iki $2004 \mathrm{~m}$. įvairias konstitucines dviprasmybes savo

${ }^{30}$ Мусияка В., „Судьи КС могут стать орудием антиконституционного переворота“, http://www.glavred. info, 20061106.

${ }^{31}$ Мусияка (27 išnaša). 
aktais užpildydavo prezidentas. Tuo tarpu tarp 2006 m. antros pusès ir 2007 m. pradžios ginčai, kuri valdžios struktūra "užpildo konstitucines tuštumas“, darèsi vis intensyvesni. Prasidèjo „sistemingas" rungtyniavimas dèl kompetencijų persiskirstymo tarp skirtingų valdžios šaku, o pirmiausia tarp ministro pirmininko ir prezidento ${ }^{32}$. Ukrainos tyrinètojai dare išvadą, o su ja negalima nesutikti, kad bandymai stiprinti bei išplèsti kurios nors vienos vykdomosios valdžios institucijos kompetenciją tik dar labiau išbalansuoja ir taip nestabilią politinę šalies sistemą. Todèl iš esmès prezidento Juščenkos idèja suformuoti konstitucinę komisiją, kuri turètų spręsti įvairias konstitucine problemas, galima būtų vertinti teigiamai (Apie tokios komisijos sudarymą prezidentas prasitarè dar 2006 m. balandžio mèn., o lapkričio mèn. prasidèjo jos formavimas.). Tiesa, toks ginču sprendimo mechanizmas gali veikti tuo atveju, jei tarp svarbiausių politiniu jègų egzistuoja konsensusas. Tačiau Regionų partija" prezidento kalbas apie pataisas konstitucinëje reformoje interpretavo, kaip bandymus apskritai atsisakyti reformos ${ }^{33}$ (Beje, 2006 m. pabaigoje vis dažniau buvo kalbama apie reformos panaikinimą. Gruodžio mèn. „Mūsų Ukraina“ parengè kreipimąsi į Konstitucinį Teismą dèl politinès reformos nelegitimumo ${ }^{34}$ ).

Atrodo, jog nauja Konstitucijos redakcija, rengiama prezidento ir jo aplinkos iniciatyva, bus labiau „proprezidentine“". Tikètina, jog diskusijos dèl Konstitucijos turinio taps dar vienu politinį Ukrainos elitą ir visuomenę poliarizuojančiu veiksniu.

\section{Kelios svarbesnès išvados}

Galima teigti, jog politinis nestabilumas išliks vienu svarbiausių Ukrainos politinès sistemos bruožu. Mūsų nuomone, politinį nestabilumą sąlygoja keletas veiksnių:

- pirma, kultūrinės ir regioninės atskirtys, skirtingos geopolitinės gravitacijos, būdingos šalies "vakarams" ir "rytams", ir toliau bus svarbiu elektoratą mobilizuojančiu veiksniu. Tokia poliarizacija ir toliau darys politinę konkurenciją kupiną įtampos ir priešiškumo. Ši aplinkybe sunkina politinių susitarimų bei koalicijų sudarymo galimybes;

- antra, mažèjant politinių ideologijų įtakai partijų identifikacijai, didejja kultūrinio ir regioninio faktoriaus įtaka. Antra vertus, svarbiausios Ukrainos politinès vis dar stipriai priklausomos nuo įtakingu verslo - oligarchiniu - grupių. Jei šiu grupių ekonominiai interesai nesutampa su galimybe partijoms susitarti, tai siekti kompromiso sekasi sunkiai;

\footnotetext{
${ }^{32}$ Рунак О., „Теория кожаной перчатки“, www.glavred.info, 20060905.

33 „Эксперт: Необходим переход к новой стадии Конституционной реформы“, http://www.korespondent. net, 20061121.

34 „Оппозиция взялась за отмену политреформы“, http://www.korespondent.net, 20061204.
} 
- trečia, politinè reforma („,konstitucinè reforma“) turèjo būti svarbus saugiklis, apsaugantis politinę sistemą nuo autoritarizmo. Prezidento galiu perdavimas ministrui pirmininkui turèjo sumažinti politinės konkurencijos intensyvumą bei priešiškumą dèl to, kas bus šalies prezidentu. Formuojama politinè sistema turëjo būti grindžiama balansu tarp „pakankamai stipraus prezidento" ir "pakankamai stipraus ministro pirmininko". Tačiau, antra vertus, būtina pažymėti, jog tokia sistema turi ir tam tikru pavojų - šalis gali išgyventi permanentišką politinę krizę ir nestabilumą, jei skirtingas politines jègas atstovaujantis prezidentas bei vyriausybès vadovas nesugeba susitarti. Politini procesą Ukrainoje komplikavo ta aplinkybe, jog nebuvo aiškių taisykliu, kaip praktikoje turètų būti sprendžiami konfliktai tarp dviejų svarbiausių vykdomosios valdžios atstovų - prezidento ir vyriausybès vadovo. Apibendrinant galima teigti, jog politinè reforma turëjo kompromisini pobūdi, kuris leido išvengti ilgos politinės krizės $2004 \mathrm{~m}$. pabaigoje - $2005 \mathrm{~m}$. pradžioje, tačiau nesprendė daugelio valstybei gyvybiškai svarbių institucinio pobūdžio klausimų.

\section{Literatūra}

1. Goldstone J., Ulfelder J., „How to Construct Stable Democracies“ The Washington Quarterly, vol. 28, Winter 2004/2005.

2. Konieczna J., „Mędzy Wschodem i Zachodem“, Fundacja Batoriego, Warszawa, 2004.

3. Moshes A., „Ukraine: Domestic Changes and Foreign Policy Reconfiguration", Political Trends in the Eastern Europe: Ukraine and Belarus (ed. by V. Silitski and A. Moshes), 2007. www.StrategicStudiesInstitute.army.mil.

4. Pigenko V., Wise Ch., Brown T. L., „Elite Attitudes and Democratic Stability: Analysing Legislators' Attitudes towards the Separation of Powers in Ukraine“" Europe - Asia Studies, vol. 54, no. 1, 2002.

5. Šatūnienė Ž., „Nepastovus posovietinès Ukrainos politinis režimas ir demokratijos konsolidavimo perspektyvos", Politologija, nr. 1, 2006.

6. "Ukraine's European Integration in Popular Perceptions", National Security and Defence, no. 7, 2005.

7. "Will democracy survive in Ukraine? What the experts say", http://www. icps.com.ua, 20070212.

8. Ведерникова И., „Кабмин в законе“, http://www.zerkalo-nedeli.com/op/ show/612/54393/, no. 33, 200609 02-08.

9. Данилов А., „Коалиция „оранжевых“ партий: террариум единомышленников“, http://www.ura-inform.com/archive/?/2006/02/15/ /60503, 20060215.

10. “Доклад Института национальной стратегии Украины (С. Белковский, К. Бондаренко, В. Вакарюк, Е. Курмашов, А. Мушак). Новый политический сезон: выборы-2006 и продолжение оранжевой революции“, Агентство политических новостей, http://www.apn.ru, 20050824. 
11. “Евгений Головаха: „Борбу между „правыми“ и „левыми“ некомпетентные политики превратили в войну между региональными и языковыми групами“, http://www.grani.kiev.ua, 20060806.

12. Мусияка В., „Судьи КС могут стать орудием антиконституционного переворота“, http://www.glavred.info, 20061106.

13. Николаенко Т., „Где Янукович потерял 300 тысяч, а Тимошенко получила 1,5 миллиона“, Украинская правда, http://www.pravda.com.ua/ru/ news/2007/10/8/65005.htm, 20071008.

14. Олещук П., „Политические партии современной Украины: между клановой системой и феодальным образованием“, Украинская правда, http://www.pravda.com. ua/ru/, 20071010.

15. “Оппозиция взялась за отмену политреформы“", http://www.korespondent.net, 20061204.

16. "Почти половина украйнцев щитает, что при Ющенко они стали жить хуже“, www.rosbalt.ru, 20051020.

17. Рунак О., „Теория кожаной перчатки“, www.glavred.info, 20060905.

18. “Чем грозит Украине партийный хаос, интервю директора Российского института стратегических исследований Е Кожохина“, http://www.izvestia.ru/world/ article3076313, 20060217.

19. “Эксперт: Необходим переход к новой стадии Конституционной реформы“, http://www.korespondent.net, 20061121.

20. “Эксперты: „Оранжевые“ министры не сработаются с Януковичем“, www. Korrespondent.net, 20060822.

21. Якименко Ю., Литвиненко А., Жданов И., „Кто и за что, с кем и против кого? Партии Украины за год до выборов“, http://www.zn.ua, 20050402. 